\title{
Approaches and challenges of traditional institutions in conservation of biodiversity: Implications for sustainable management of natural resources in Nigeria
}

\author{
L. N. Sambe ${ }^{1}$, G. O. Yager $^{2} *$ P. N. $\operatorname{Ver}^{3}$ and M. O. Ikape ${ }^{1}$ \\ ${ }^{1}$ Department Social and Environmental Forestry, Federal University of Agriculture, Makurdi, Nigeria \\ ${ }^{2}$ Department of Wildlife and Range Management, Federal University of Agriculture, Makurdi, Nigeria \\ ${ }^{3}$ Department of Science Laboratory Technology, Federal Polytechnic Nasarawa State, Nigeria \\ *Corresponding Author: gbrlyager@gmail.com
}

\begin{abstract}
The study assessed indigenous practices and beliefs on the conservation of natural resources in Oju Local Government Area of Benue State. Purposeful and simple random sampling was applied to determine the study sample and thus a sample size of 118 was used for the study. The findings revealed that majority of the respondents were male (75.4\%) while $24.6 \%$ were female. The indigenous and traditional beliefs in the protection of natural resources in the area is reflected in a variety of their practices which included sacred groves and sacred landscapes, construction of masquerades and other traditional artifacts, reflecting greatly the population of the forest resources. The most conserved fauna and flora species identified were; Smutsia gigantea, Elgaria coerulea, Ceyx erithaca, Milvus aegyptius, Centropus steerii and Ophiophagus hannah; Vitellaria paradoxa, Khaya grandifoliola and Abies balsamea. Major challenges identified were; lack of inclusion by governance institution with (98.7\%), followed by adoption of other religious beliefs with (97.5\%), poaching/illegal logging and population growth/urbanization (91.5\%), perception of idolatry (88.9\%), Bush fires $(89.8 \%)$ while frequent use of herbs for traditional medicine $(83.1 \%)$ had the least percentage. On the ways of improvement was awareness creation had the highest proportion (33.9\%), followed by attitudinal change (30.5\%), while resource allocation to traditional leaders and integration of traditional conservation in formal resource conservation had the least proportion of $17.8 \%$. It was concluded that traditional practices and beliefs if well managed will enhanced proper conservation and management of natural resources. The study thus recommended that, institutions responsible for conservation of natural resources should be positioned for effective performance and service delivery. Government should have monitoring agents that will help in ensuring natural resource conservation.
\end{abstract}

Keywords: Traditional institution, Traditional beliefs, Biodiversity conservation, Sustainable management.

\section{INTRODUCTION}

Traditional institutions are vibrant and organized on the basis of their religion and cultural beliefs to effectively manage natural resources, occupying a unique position in the management of natural resources. They are widely accepted by their subjects as the religious, political, judicial and the spiritual embodiment of their communities and therefore take obligation in the management of community resources (Millar, 2004; Ngara \& Mangizvo, 2013).

Sustainable development and biodiversity sustainability demand effective conservation and management strategies among important protected areas and values among locality. It is the management of valuable natural resources such as timber, topsoil, and minerals, forests, wildlife, parkland, and wilderness and watershed areas (Rim-Rukeh et al., 2013). The conservation of natural resources in general has been an issue of concern and hence the growing needs to reduce the extinction of natural resources. Rapid decline in biological diversity - species, ecosystems, and genetic diversity is one of the critical challenges of the $21^{\text {st }}$ century (Fongjong, 2008).

Successful conservation of the environment and biodiversity especially hang even more on the traditional beliefs, cultural norms and practices (Berkes et al., 2000; Lingard et al., 2003; Sasaki et al., 2010). However, traditional practices and beliefs are rapidly eroding worldwide. The resultant breakdown of informal, self-imposed restrictions on land and resource use has threatened species and habitats that were once afforded protection by traditional practices (Anoliefo et al., 2003; Lingard et al., 2003; Bhagwat \& Rutte, 2006). The disregard for these traditional checks and balances especially among modern communities has adversely affected their enforcement. The abandonment of traditional cultural practices is doing harm that goes beyond the abrogation of traditional cultural practices to serious threat to natural environmental structures (Anoliefo et al., 2003). The decline in tradition approach is a characteristic of developing countries, and this create room for instability in biodiversity conservation worldwide (Groombridge, 1992).

Problems of global warming and a host of other have plagued humanity. These necessitate the need to check and 
balance the activities in the wild to ensure preservation of values/norms and most especially the environment. Natural resources losses occasioned by many factors threatened to both human and animal survival. The loss of each species comes with the loss of potential economic benefits, as well as loss of ecosystem balance (Kideghesho, 2008). Despite the important role played by traditional African belief systems in natural resource management and conservation, still the institution is neglected. According to Appiah-Opoku (2006), indigenous knowledge systems are now being unjustly negated as they are viewed in some quarters as somehow inherently primitive. Although efforts to integrate rural people into the conservation of natural resource programmes and projects have been in place for quite some time but its integration has been slow (Hulme \& Murphree, 1999). This recognition has stimulated study interest in the area because there is lack of in-depth knowledge of the role of traditional belief in conservation of natural resources in the study area. Hence the objective of this research is to assess the role of traditional practices and beliefs in conservation of natural resources in the study area.

There is and inextricable link between the culture, beliefs and norms of the people in the preservation of the environment and biodiversity conservation (Anoliefo et al., 2003). This is also noticeable in the people's farming systems, care for the land, forests, wild life and streams. The rural people are oldest inhabitants of an area who have lived in their traditional homeland for many generations (Toledo, 2000). Hence it is easier for them to pass on the knowledge about their environment from one generation to another. There is a growing consensus that traditional institutions provide considerable protection of ecosystems and biodiversity without governmental juridical restrictions (Barrow \& Pathak, 2005; Tengo et al., 2007; Jones et al., 2008; Dudley et al., 2009). Also, there are no documented records of traditional beliefs practices used for conservation of natural resources in the study area. Based on literature search, there are no concrete documents to show reasons for adherence to traditional belief in the study area.

\section{METHODOLOGY}

\section{Study area}

The Oju Local Government Area (LGA) is one of the 23 Local Government Areas (LGAs) of Benue State located in the South part of the state and lies between latitude $6^{\circ} 85^{\prime} \mathrm{N}$ and $8^{\circ} 41^{\prime} \mathrm{N}$ and longitude $6^{\circ} 51^{\prime} \mathrm{E}$ and $8^{\circ} 25^{\prime} \mathrm{E}$. It was created in 1976 with three districts namely; Igede district, Uwokwu districts and Ito districts and bounded in the north by her immediate neighbour, Obi Local Government Area, Ebonyi State and Cross River State, to the East by Vandeikya, Konshsha and Gwer, to the West by Ado Local government area. Basically, the two predominant religions in the area are Christianity and traditional African religion.

The topographic feature had long range of highlands which make the area prone to water inferno, which destroys food crops, houses as well as property yearly (Hula, 2010). The vegetation comprise of relics of the guinea savannah with coarse grasses and numerous species of scattered trees which include Khaya senegalensis (Desr.) A.Juss., Daniellia oliveri (Rolfe) Hutch. \& Dalziel, Isoberlinia doka Craib \& Stapf, Parkia biglobosa (Jacq.) Benth., Prosopis africana (Guill. \& Perr.) Taub., Vitellaria paradoxa C.F.Gaertn. and Burkea africana Hook. (Hula, 2010). However, persistent in anthropogenic activities creates fragmentation of the remaining patches of the very few forested land in the area (Nyagba, 1995). The Climatic seasonal are wet and dry seasons. Rainfall ranges between 12,000 to 20,000 mm, while dry season sets in November and ends in March (Nyagba, 1995). Temperatures are constantly high averaging between $28^{\circ} \mathrm{C}$ to $32^{\circ} \mathrm{C}$ and sometimes rising to $37^{\circ} \mathrm{C}$. Dominant agricultural crops include; yams, cassava, rice, maize, millet, groundnut, guinea corn, soybeans etc. in addition to fishing, basking, carving, hunting, knitting and pottery. Major natural tourist sites include Illeme water lake, Okilema, Andibilla Hills, Ohuma-Uwokwu Hills, local iron production at Ogengeng Ukpa; water spring at Uwu Ukpa among others. These are in addition to the wonderful bats community at Ojokwe Uwokwu.

\section{Population sample and study design}

The study population comprises of both men and women who are actively involved in indigenous practices and beliefs relating to biodiversity conservation. Stratified and purposive sampling techniques were used to select sampled areas and respondents in the study area. In the first stage, a stratified sampling technique was used and a sampling intensity of $30 \%$ was applied to select three (3) out of the eleven council wards based on the prevalence of indigenous beliefs practices in the study area. Thus three (3) wards namely; Ibilla council ward, Oju council ward and Iyeche council ward were chosen. In the second stage, a purposive sampling technique was used to select four (4) villages from each ward making a total of twelve (12) villages. In each of the selected villages, ten 10 individuals made up of traditional chiefs, village priests and households such as hunters, bush meat traders, traditional healers and farmers were randomly selected for interview. This gives a total sample size of one hundred and twenty (120) respondents, however 118 responses were analysed. A semi structured questionnaire and interviews were employed for data collection. 


\section{Data analysis}

Data collected were analyzed using descriptive and inferential statistics.

\section{RESULTS}

\section{Socio-economic characteristics of respondents}

The results of the demographic data of respondents are presented in table 1. The results indicated that majority (75.4\%) of the respondents were males while $24.6 \%$ were females. The age distribution of respondents' majority $(55.1 \%)$ of the respondents was 50 years and above indicating their long-time interaction with the environment and familiarity with the fauna and flora resources. This was followed by $21.2 \%$ for those between ages $40-49$, while less than 30 years of age were $7.6 \%$. In terms of marital status, $92.4 \%$ of the respondents were married, only $7.6 \%$ were single. Based on educational qualification, majority $(61 \%)$ of the respondents had primary education only, $23.7 \%$ had informal education while $9.3 \%$ and $5.9 \%$ had tertiary education secondary education respectively.

Table 1. Demographic data of respondents.

\begin{tabular}{|c|c|c|c|}
\hline Variables & & Frequency & Percentage \\
\hline \multicolumn{4}{|l|}{ Gender } \\
\hline Male & & 89 & 75.4 \\
\hline \multirow[t]{2}{*}{ Female } & & 29 & 24.6 \\
\hline & Total & 118 & 100 \\
\hline \multicolumn{4}{|l|}{ Age } \\
\hline Under 30 & & 9 & 7.6 \\
\hline $30-39$ & & 19 & 16.1 \\
\hline $40-49$ & & 25 & 21.1 \\
\hline \multirow{2}{*}{50 and above } & & 65 & 55.1 \\
\hline & Total & 118 & 100 \\
\hline \multicolumn{4}{|l|}{ Marital status } \\
\hline Married & & 109 & 92.4 \\
\hline Single & & 9 & 76.6 \\
\hline \multirow{2}{*}{ Divorced } & & 0 & 0.0 \\
\hline & Total & 118 & 100 \\
\hline \multicolumn{4}{|c|}{ Educational qualification } \\
\hline No formal education & & 28 & 23.7 \\
\hline Primary & & 72 & 61.0 \\
\hline Secondary & & 7 & 5.9 \\
\hline Tertiary & & 11 & 9.3 \\
\hline & Total & 118 & 100 \\
\hline
\end{tabular}

Source: Field survey, 2018.

\section{Indigenous beliefs and practices for conservation}

The result of indigenous beliefs and practices presented in table 2 indicates a $100 \%$ response that the Ipinu sacred forest in Anyougbu of Ibilla, indigenes doesn't enter without proper acknowledgement. Again, 100\% of the respondents agreed that wild custard apple (Annona senegalensis Pers.) is believed to prevent snake bites and if bitten by mistake the leaves are used for treatment of such bites. More so, 100\% of the respondents agreed that a Witch bird (Centropus senegalensis) is believed to give bad luck and that the leaves of Newbouldia laevis (P.Beauv.) Seem. ex Bureau is believed to have healing power. The result also raveled $100 \%$ respondents agreeing that Village square in Ibilla is sacred and as such no activity is carried out there like exploration, felling of trees, fuel wood extraction.

On the no fishing period's variables $90.7 \%$ of the respondents agreed that there no fishing is done on no periods, a practice by the indigenes in influencing the conservation of biodiversity, while $9.3 \%$ disagreed. In terms of the farming system (bush fallowing) practice, $85.6 \%$ of the respondents agreed that they practice the system while $14.4 \%$ of the respondents disagreed. More so, $89.8 \%$ of the respondents agreed that there are pieces of land set aside for spiritual purpose. These grooves are reputed to be resting home of some respected traditional spirits while only $10.2 \%$ disagreed. Majority of the respondents $(89.8 \%)$ agreed that there is Ban or restrictions to certain areas of the forest while only $10.2 \%$ disagreed with the statement. Also, $94.5 \%$ the respondents agreed that Chlorophora excelsa (Welw.) C.C. Berg and Khaya ivorensis A. Chev. are considered trees with spirits and should not be felled without rituals being done, while $5.9 \%$ did not agree.

On the belief that forests are ancestral homes to some deities, 91.5\% of the respondents accepted the belief. Also majority $(90.7 \%)$ of the respondents were aware of the prohibition of lumbering by our ancestral history. On the sale of forestry and wildlife products $92.4 \%$ of the respondents accepts that wildlife such as Python are not hunted of traded. Also majority $(92.4 \%)$ indicated that certain tree species have ancestral history and so are left untouched while $93.2 \%$ of the respondents agreed that Khaya ivorensis is believed to house ancestral gods and so have restricted access. 
Table 2. Indigenous beliefs and practices influencing conservation biodiversity in the study area.

\begin{tabular}{|c|c|c|c|}
\hline Beliefs/practices & Response & Frequency & Percentage \\
\hline The Ipinu in Anyougbu Ibilla, indigenes don't enter without proper & Yes & 118 & 100 \\
\hline \multirow[t]{2}{*}{ acknowledgement } & No & 0 & 0 \\
\hline & Total & 118 & 100 \\
\hline Wild custard apple (Annona senegalensis Pers.); is believed to prevent & Yes & 118 & 100 \\
\hline \multirow{2}{*}{$\begin{array}{l}\text { snake bites and if bitten by mistake the leaves are used for treatment of } \\
\text { such bites. }\end{array}$} & No & 0 & 0 \\
\hline & Total & 118 & 100 \\
\hline \multirow[t]{3}{*}{ Witch birds (Culculus senegalensis) it is believed to give bad luck } & Yes & 118 & 100 \\
\hline & No & 0 & 0 \\
\hline & Total & 118 & 100 \\
\hline The leaves of newbouldia laevis (P.Beauv.) Seem. ex Bureau is believed & Yes & 118 & 100 \\
\hline \multirow{2}{*}{ to have healing power } & No & 0 & 0 \\
\hline & Total & 118 & 100 \\
\hline & Yes & 118 & 100 \\
\hline \multirow{2}{*}{ there like exploration, felling of trees, fuel wood extraction } & No & 0 & 0 \\
\hline & Total & 118 & 100 \\
\hline Chlorophora excelsa (Welw.) C.C. Berg and African Mahogany (Khaya & Yes & 111 & 94.1 \\
\hline ivorensis A. Chev.) are considered trees with spirits and should not be & No & 7 & 5.9 \\
\hline felled without some rituals were done. & Total & 118 & 100 \\
\hline \multirow[t]{3}{*}{ No fishing periods } & Yes & 107 & 90.7 \\
\hline & No & 11 & 9.3 \\
\hline & Total & 118 & 100 \\
\hline \multirow[t]{3}{*}{ Farming system (Bush fallowing) } & Yes & 101 & 85.6 \\
\hline & No & 17 & 14.4 \\
\hline & Total & 118 & 100 \\
\hline \multirow{3}{*}{$\begin{array}{l}\text { These are pieces of land set aside for spiritual purpose, These grooves } \\
\text { are reputed to be resting home of some respected traditional spirits }\end{array}$} & Yes & 106 & 89.8 \\
\hline & No & 12 & 10.2 \\
\hline & Total & 118 & 100 \\
\hline \multirow[t]{3}{*}{ Ban or restrictions to certain areas of the forest } & Yes & 106 & 89.8 \\
\hline & No & 12 & 10.2 \\
\hline & Total & 118 & 100 \\
\hline \multirow{3}{*}{$\begin{array}{l}\text { It is believed that some forests are ancestral homes to some deities and } \\
\text { so are restricted areas }\end{array}$} & Yes & 95 & 91.5 \\
\hline & No & 23 & 8.5 \\
\hline & Total & 118 & 100 \\
\hline \multirow[t]{3}{*}{ Lumbering was prohibited by our ancestral history. } & Yes & 107 & 90.7 \\
\hline & No & 11 & 9.3 \\
\hline & Total & 118 & 100 \\
\hline \multirow{3}{*}{$\begin{array}{l}\text { There is restriction in the sale of forestry and wildlife products hence } \\
\text { promoting conservation }\end{array}$} & Yes & 109 & 92.4 \\
\hline & No & 9 & 7.6 \\
\hline & Total & 118 & 100 \\
\hline \multirow[t]{3}{*}{ Some tree species have ancestral history and so are left untouched } & Yes & 109 & 92.4 \\
\hline & No & 9 & 7.6 \\
\hline & Total & 118 & 100 \\
\hline \multirow{3}{*}{$\begin{array}{l}\text { African Mahogany (Khaya ivorensis A. Chev.) is believed to house } \\
\text { ancestral gods }\end{array}$} & Yes & 110 & 93.2 \\
\hline & No & 8 & 6.8 \\
\hline & Total & 118 & 100 \\
\hline
\end{tabular}

\section{Species conserved by indigenous beliefs and practices}

The result of the fauna and flora species conserved by the various beliefs and practices in the study area is given in tables 3 and 4. All the responses (100\%) in table 3 indicated that the Giant Ground Pangolin (Smutsia gigantea) and Alligator lizard (Elgaria coerulea) are among animal species conserved by indigenous beliefs and practices. This was followed by Dwarf Kingfisher (Ceyx erithaca) (93.2\%) and Yellow-billed Kite (Milvus aegyptius) (93.2\%), Blackhooded Coucal (Centropus steerii) (92.4\%), Royal Python (Python regius) (83.9\%), King Cobra (Ophiophagus hannah) $(89.9 \%$ ), while $89 \%$ and $81.4 \%$ indicated for Bushbuck (Tragelaphus scriptus) and for Spotted Hyena (Crocuta crocuta) respectively. Among tree species conserved by belief and practices, the entire respondent agreed $100 \%$ for Vitellaria paradoxa C.F.Gaertn. and Khaya grandifoliola C.DC.; while Abies balsamea (L.) Mill. (91.5\%), Ostrya virginiana (Mill.) K.Koch (89.8\%) and Parkia biglobosa had (80.5\%).

Table 3. Fauna species conserved by indigenous beliefs and practices in the study area.

\begin{tabular}{llrrr}
\hline Species & Scientific name & Response & Frequency & Percentage \\
\hline Bushbuck & Tragelaphus scriptus & Yes & 105 & 89.0 \\
& & No & 13 & 11.0 \\
Spotted Hyena & Total & 105 & 89.0 \\
& Crocuta crocuta & Yes & 96 & 81.4 \\
& & No & 22 & 18.8 \\
& & Total & 118 & 100 \\
\hline
\end{tabular}




\begin{tabular}{lcrrr}
\hline Giant Ground Pangolin & Smutsia gigantea & Yes & 118 & 100 \\
& & No & 0 & 0 \\
Alligator lizard & Elgaria coerulea & Total & 118 & 100 \\
& & Yes & 118 & 100 \\
& & No & 0 & 0 \\
King Cobra & Ophiophagus hannah & Total & 118 & 100 \\
& & Yes & 106 & 89.9 \\
& & No & 12 & 10.2 \\
Royal Python & Python regius & Total & 118 & 100 \\
& & Yes & 99 & 83.9 \\
& & No & 19 & 16.1 \\
Yellow-billed Kite & Milvus aegyptius & Total & 118 & 100 \\
& & Yes & 110 & 93.2 \\
Dwarf Kingfisher & Ceyx erithaca & No & 8 & 6.8 \\
& & Total & 118 & 100 \\
& & Yes & 110 & 93.2 \\
Black-hooded Coucal & Centropus steerii & No & 8 & 6.8 \\
& & Total & 118 & 100 \\
& & Yes & 109 & 92.4 \\
& & No & 9 & 7.6 \\
& & Total & 118 & 100 \\
\hline Sources & & &
\end{tabular}

Source: Field survey, 2018.

Table 4. Plant species conserved by indigenous beliefs and practices in the study area.

\begin{tabular}{llrrr}
\hline Species & Scientific name & Response & Frequency & Percentage \\
\hline Shea Butter Tree & Vitellaria paradoxa C.F. & Yes & 118 & 100 \\
& Gaertn. & No & 0 & 0 \\
African Mahogany & Total & 118 & 100 \\
& & Yes & 118 & 100 \\
& & No & 0 & 0 \\
Balsam Tree & & Total & 118 & 100 \\
& Abies balsamea (L.) Mill. & Yes & 108 & 91.5 \\
& & No & 10 & 8.5 \\
Black Plum & Syzygium cumini (L.) Skeels. & Total & 118 & 100 \\
& & Yes & 103 & 87.3 \\
Gambia Mahogany & No & 15 & 12.7 \\
& & Total & 118 & 100 \\
Kalm Tree & Yes & 103 & 87.3 \\
& A.Juss. & No & 15 & 12.7 \\
& & Total & 118 & 100 \\
Iron Tree & Elaeis guineensis Jacq. & Yes & 98 & 83.1 \\
& & No & 20 & 16.9 \\
& & Total & 118 & 100 \\
Locust Bean & Yes & 106 & 89.8 \\
& K.Ktrya virginiana (Mill.) & No & 12 & 10.2 \\
& & Total & 118 & 100 \\
& Parkia biglobosa (Jacq.) & Yes & 95 & 80.5 \\
& Benth. & No & 23 & 19.5 \\
& & Total & 118 & 100 \\
\hline
\end{tabular}

Source: Field survey, 2018.

\section{Challenges on sustainability of indigenous beliefs and practices used for conservation}

The result of the challenges on sustainability of traditional beliefs and practices in table 5 revealed that the highest proportion $(97.5 \%)$ respondents indicated for adoption of Other religious beliefs as the major challenge, this was followed by lack of inclusion of governance institution, population growth/urbanization and illegal poaching (91.5\%), bush fires $(89.8 \%)$, agricultural activities $(89.0 \%)$, perception of idolatry $(88.9 \%)$ and the least frequent harvest of herbs for traditional medicines $(83.1 \%)$.

Table 5. Challenges of indigenous beliefs and practices of conservation in the study area.

\begin{tabular}{lrrr}
\hline Challenge & Response & Frequency & Percentage \\
\hline Population growth/Urbanisation & Yes & 108 & 91.5 \\
& No & 10 & 8.5 \\
& Total & 118 & 100 \\
Agricultural Expansion & Yes & 105 & 89.0 \\
& No & 13 & 11.0 \\
& Total & 118 & 100 \\
\hline
\end{tabular}




\begin{tabular}{lrrr}
\hline Adoption of other religious beliefs & & & \\
& Yes & 115 & 97.5 \\
& No & 3 & 2.5 \\
Perception of idolatry & Total & 118 & 100 \\
& Yes & 105 & 88.9 \\
& No & 3 & 2.5 \\
Lack of inclusion by governance institution & Total & 118 & 100 \\
& Yes & 116 & 98.3 \\
Bush fires & No & 2 & 1.7 \\
& Total & 118 & 100 \\
Poaching/Illegal logging & Yes & 106 & 89.8 \\
& No & 2 & 10.2 \\
Frequent harvest of herbs for traditional medicines & Total & 118 & 100 \\
& Yes & 108 & 91.5 \\
& No & 10 & 8.5 \\
& Total & 118 & 100 \\
\hline
\end{tabular}

Source: Field survey, 2018.

\section{Ways of improving traditional conservation of natural resources}

The result on the ways of improving traditional conservation of natural resources in the study area in table 6 shows that, awareness creation had the highest percentage $(33.9 \%$,), this was followed by attitudinal change (30.5\%), resources allocation to traditional leaders and the integration of traditional conservation in formal conservation strategies had $17.8 \%$ respectively.

\begin{tabular}{|c|c|c|}
\hline Ways of improvement & Frequency & Percentage \\
\hline Resources Allocation to traditional leaders & 21 & 17.8 \\
\hline Awareness Creation & 40 & 33.9 \\
\hline Attitudinal change & 36 & 30.5 \\
\hline Integration of traditional conservation in formal resource conservation & 21 & 17.8 \\
\hline Total & 118 & 100.0 \\
\hline
\end{tabular}

Source: Field survey, 2018.

\section{DISCUSSION}

The sex might be as a result of the fact that the communities encouraged participation of males in issues of strict adherence to traditional practices and belief's. The higher proportion of respondents' agreement to these beliefs and practices is indications that these are practices are still observed in the study area. A similar outcome was observed by Jimoh et al. (2012) in their research involving the communities of Oban hills of the Cross River National Park (CRNP) where cultural beliefs on forbidden forests hosting shrines were located, fishing and hunting taboos were observed. These findings are in agreement with those of (Berkes et al., 2000; Lingard et al., 2003; Sasaki et al., 2010) who asserted that religious beliefs, traditional beliefs, cultural norms and practices play a crucial role for the successful conservation of the environment and specific organisms especially in the developing countries and even in the Western world, where so much has been given to the relationship between culture and history; and conservation of protected areas (Infield, 2002). According to Toledo (2000), this knowledge and beliefs about the environment are passed from one generation to another. This finding also agrees with that of Appiah-Opoku (2006) in Nigeria. Like any other African society, ancestral veneration plays a critical role in the conservation of resources because they believe that ancestors can punish a person who violates traditionally sanctioned norms or destroys the environment. Resource exploitation through activities such as farming, hunting, and tree cutting are prohibited in these places until certain rituals are performed. The sacred groves harbour economically and socially important ecological species (AppiahOpoku, 2006). In Nigeria and especially among the Igbo community and others ethnic groups, management and conservation of the natural resources (especially "sacred groves) were best safeguarded through the use of traditional taboos (laws) and sanctions (Anoliefo et al., 2003).

There are many studies in Africa that submits that incorporating cultural norms and taboos into conservation programs may provide incentives to communities to conserve natural resources. In Madagascar for instance, Lingard et al. (2003), Schachenmann (2006), Tengo et al. (2007), Jones et al. (2008) and Rabearivony et al. (2008) reported the relevance of taboos and cultural laws in ensuring the sustenance forest biodiversity. Studies in Ghana also revealed that the use of taboos in clans was effective in the protection of their natural resources (Hen, 2006; Saj et al., 2006; SarfoMensah \& Oduro, 2007; Kobina \& Kofi, 2009). Similar cases were also recorded in Nigeria (Anoliefo et al., 2003; Banjo et al., 2006; Obasohan, 2008; Akindele, 2010). 
The findings of Chemhuru \& Masaka (2010) in Zimbabwe among the Shona people revealed that even though the Shona people have been exposed to cultural globalization, they continue to be guided by their values, taboos and beliefs in the conservation and management of their natural resources. The Shona people exhibit an unconscious appreciation of certain environmental taboos which informs an esoteric environmentally based knowledge that is meant at sustainable use of nature's resources, hence Shona taboos are specifically fundamental in preserving the environment, and protection of water sources, the natural vegetation and wildlife, and endangered nonhuman species. The above are critical and sources of environmental ethics, propagating a synergy between human and the biodiversity at large.

On the belief that spirit lives in trees and sacred places is supported by Wilson (1989) who maintained that in most African communities, the ancestral spirits are believed to be living in the forests and special trees, caves and ruined homes and water bodies. These environmental components are therefore cared for to ensure limited human access into them lest the spirits be offended and driven away homeless. So, falling trees was taboo in a sacred place. According to Hyland \& Ikumenne (2005) the Ndebele, it is taboo for clan members to kill animals which serve as the revered symbol within or running into a sacred forest because they belong to Mwari and the ancestral spirits.

\section{Challenges of traditional conservation of natural resources}

Challenges identified in this study were similar to challenges reported by other authors (Anoliefo et al., 2003; Saj et al., 2006; Jimoh et al., 2012; Amonum et al., 2017; Egbodo, 2008). Influx of foreign religion and tag of traditional beliefs as idolatry were the most pressing problems facing traditional methods of conservation of natural resources in the study area. According to Egbodo (2008), the advent of Christianity dramatically creates room for deviation from Igede ancestral identities and their symbols. Influx of religion plays a role as many who belong to Western religion now see some of these taboos and totems as being satanic. Finding of the study agrees with report by Saj et al. (2006) reported that the Saviour Church of Ghana, encouraged their members to hunt monkey which is a taboo among the people, this have affected the population of monkey. In Nigeria, Anoliefo et al. (2003) reported that, many local people in Nigeria have embraced Christianity and hence shun traditional religion and its taboos.

Another challenge of conservation of natural resources in the area was population growth and urbanization. The increase in the population of human beings results in the increase in the rate of exploration and exploitation of natural resources. This agrees with Onuche (2010), who noted that exploitation that outstrips regeneration constitutes a threat to the sustainability of forest resources in the study area. Increase in human population resulted in over- exploitation natural resources. To satisfy these needs, pressure is mounted on the natural resources resulting in over-exploitation. Rise in demand for fuel-wood, pulpwood, poles, and other types of wood for building purposes as reasons for much pressure on the forest.

Also, agricultural activities were among pressing challenges of traditional conservation of natural resources. Farming activities start with forest clearing and bush burning which leads to deforestation of natural resources. Uloko \& Yager (2017) identified agricultural expansion as the one of the major causes of deforestation in Nigeria. Deforestation occurs in areas with heavy dependence on forest lands for subsistence and shifting agriculture largely found in developing countries. The study also indicated that disrespect and poor interest in the traditional practices amongst the youth was a challenge. Hence, Sarfo-Mensah \& Oduro (2007) stated that rapid change in the belief systems among rural folks (notably the youth) is indeed a major hindrance to effective traditional practices.

\section{Ways of improving traditional conservation of natural resources}

On ways of improving conservation of natural resources in the study area, was awareness creation as the most needful way of improving resources conservation. This is because awareness creation can help to educate the people on the importance and benefits of resources conservation and also in capacity building for traditional authorities for effective management. It will also help to a great extent by creating environmental awareness among the general public. This will also help in promoting the consciousness in the communities towards a balanced ecology for sustainable conservation of natural resources. According to Awedora (2002), education and awareness creation help traditional authorities to develop their managing skills in conservation of natural resources. Another way of improving conservation of natural resources in the area is through attitudinal change toward natural resources which will stimulate the community to discourage people from sneaking into the grove/forest at night thereby exploiting the resources.

Based on resources allocation among local authority as a way of improving natural resources management, if the communities are aware of the benefits and values of the resources in their direct control, they can effectively protect the resources. Fairhead \& Leach (2004) stated that government structures have alienated resource control from local people and this has accounted for natural resources management failures.

\section{CONCLUSION AND RECOMMENDATION}

The study inferred that traditional beliefs, taboos and cultural practices played some roles in wildlife conservation in 
the study area. Similarly, there were wildlife species that are forbidden, either due to cultural taboo, religious reasons, personal dislike or tradition. However, dwindling powers of traditional authorities and cultural erosion due to modernization and embracement of western religion limits the efficiency of the application of these traditional conservation measures. Religious beliefs, traditional beliefs, cultural mores and practices play a crucial role for the successful conservation of plant and animal species and the environment in the study area. Thus the promotion of these beliefs will contribute to biodiversity conservation and sustainable development of our society.

We recommend that, there is need for awareness creation on the importance of conservation of these natural resources. There should be institutional support to strengthen and enforce compliance within those communities regardless of individual beliefs or place of origin to ensure sustenance and Government should have monitoring agents that will help in ensuring natural resource conservation.

\section{ACKNOWLEDGEMENTS}

We wish to thank the Igede Uwokwu and Ito districts for their availability and willingly to assist in this research and also appreciate those who helped during the data collection.

\section{REFERENCES}

Akindele S.O. (2010). Forest Restoration through Traditional Institutions in Nigeria: Challenges and Prospects. Retrieved from: http://www.cfc2010.org/papers/session13/Akindele-s13.pdf

Amonum J.I., Dawaki S.A. \& Dachung G. (2019). Effects of Plant Species on the Physico-chemical Properties of Soil in Falgore Game Reserve, Kano State, Nigeria. Asian Journal of Environment \& Ecology, 9(4): 1-11.

Anoliefo G.O., Isikhuemhen O.S. \& Ochije N.R. (2003). Environmental implications of the erosion of cultural taboo practices in Awka-South Local Government Area of Anambra State, Nigeria: 1. Forests, trees, and water resource preservation. Journal of Agricultural and Environmental Ethics, 16: 281-296.

Appiah-Opoku S. (2007). Indigenous beliefs and environmental stewardship: a rural Ghana experience. Journal of Cultural Geography, 22: 79-88.

Awedora A.K. (2002). Culture and Development in African with Special reference to Ghana. Institute of African Studies, University of Ghana, Lagon.

Banjo A.D., Otufale G.A., Abatan O.L. \& Banjo E.A. (2006). Taboo as a means of plant and animal conservation in South-Western Nigeria: A case study of Ogbe River and its Basin. World Applied Sciences Journal, 1: 39-43

Barrow E. \& Pathak N. (2005). Conserving "unprotected" protected areas - communities can and do conserve landscapes of all sorts. In the protected landscape approach: Linking nature, culture and community. In: Brown J., Mitchell N. and Beresford M. (Eds.) The Protected Landscape Approach Linking Nature, Culture and Community. IUCN, Gland, Switzerland, pp. 65-80.

Berkes F., Colding J. \& Folke C. (2000). Rediscovery of traditional ecological knowledge as adaptive management. Ecological Applications, 10: 1251-1262.

Bhagwat S.A. \& Rutte C. (2006). Sacred groves: Potential for biodiversity management. Frontiers in Ecology and Environment, 4 : 519-524.

Chemhuru M. \& Masaka D. (2010). Taboos as sources of Shona Peoples Environmental Ethics. Journal of Sustainable Development in Africa, 12(7): 13.

Dudley N.L., Higgins Z. \& Mansourian S. (2009). The links between protected areas, faiths, and sacred natural sites. Conservation Biology, 23: 568-577.

Egbodo B.A. (2008). Igede Tradtional Customs and paradox of modernism. Austuma Educational Resources, 18 AB way, Otukpo, Benue State, Nigeria, pp. 3-19.

Fairhead J. \& Leach M. (2004). False Forest History, Complicit Social Analysis: Rethinking. Some West African Environmental Narratives. Environment, Development and Rural Livelihoods. Earthscan, UK and USA.

Fongjong L.N. (2008). Gender Roles and practices in natural resource management in the North West Province of Cameroon. Local Environment, 13(5): 461-475.

Groombridge B. (1992). Global biodiversity: Status of the earth's living resources. Chapman and Hall, New York, pp. 1-25.

Hen L. (2006). Indigenous knowledge and biodiversity conservation and management in Ghana. Journal of Human Ecology, 20(1): 21-30.

Hula M.A. (2010). Population Dynamics and vegetation change in Benue State, Nigeria. Journal of Environment Issues and Agriculture in Developing Countries, 2(1): 17.

Hulme D. \& Murphree M. (1999). Communities, wildlife and the 'new conservation in Africa. Journal of International Development, 11: $11-285$.

Hyland A.D.C. \& Ikumenne S. (2005). Place, tradition and memory: Tangible aspects of the intangible heritage in the cultural landscapes of zimbabwe: A case study of the matobo hills. In: $10^{\text {th }}$ international seminar: Cultural Landscapes in the $21^{\text {st }}$ Century. pp. 11-16.

Infield M. (2002). Cultural values: A forgotten strategy for building community support for protected areas in Africa. Conservation Biology, 15: 800-802.

Jimoh S.O., Ikyaagba E.T., Alarape A.A., Abioha E.E. \& Adeyemi, A.A. (2012). The Role of Traditional Laws and Taboos in 
Wildlife Conservation in the Oban Hill Sector of Cross River National Park (CRNP), Nigeria. Journal of Human Ecology, 39(3): 209-219.

Jones J.G., Andriamarovololona M.M. \& Hockley N. (2008). The importance of taboos and social norms to conservation in Madagascar. Conservation Biology, 22: 976-986.

Kideghesho J.R. (2008). Co-existence between the traditional societies and wildlife in Western Serengeti, Tanzania: Its relevance in contemporary wildlife conservation efforts. Biodiversity Conservation, 17: 1861-1881.

Kobina E.D. \& Kofi A.A. (2009). Change and Continuity: Using Indigenous Knowledge to Achieve Environmental Sustainability in Ghana. In: $7^{\text {th }}$ International Science Conference on the Human Dimensions of Global Environmental Change held in Germany, Bonn, on $26^{\text {th }}-30^{\text {th }}$ April, 2009 on the Theme: The Social Challenges of Global Change. pp. 35-42.

Lingard M., Raharison N., Rabakonandrianina E., Rakotoarisoa J. \& Elmqvist T. (2003). The role of local taboos in conservation and management of species: The radiated tortoise in Southern Madagascar: Conservation and Society, 1: 223-246

Millar D. (2004). Shrines and Groves: Bio-cultural Diversity and Potential Environment. pp. 1-30.

Ngara R. \& Mangizvo V.R. (2013). Indigenous knowledge systems and the conservation of natural resources in the shangwe community in Gokwe district, Zimbabwe. International Journal of Asian Social Science, 23: 23-42.

Nyagba J.L. (1995). The Geography of Benue State. In: Denga D.J. (Ed.) Benue State the Land of Great Potentials: A Compendium. Rapid Educational Publisher Limited, Calabar, Nigeria, pp. 20-28.

Obasohan E.E. (2008). Fisheries biodiversity: The role of a traditional taboo/ritual prohibition in the management and conservation of the fish resources of Ibiekuma Stream in Ekpoma, Edo State, Nigeria. Bioscience Research Communications, 20: 257-264.

Onuche U. (2010). Impact of poverty on the sustainability of forest in Nigeria: implication for sustainable forest reduction in Global warming. Journal of Sustainable Development in Africa, 12(6): 208-215.

Rabearivony J., FanamehaI E., Mampiandra J. \& Thorstrom R. (2008). Taboos and social contracts: Tools for ecosystem management -lessons from the Manambolomaty Lakes RAMSAR site, western Madagascar. Madagascar Conservation and Development, 3: 7-16.

Rim-Rukeh A., Irerhievwie G. \& Agbozu I.E. (2013). Traditional beliefs and conservation of natural resources: Evidences from selected communities in Delta State, Nigeria. International Journal of Biodiversity and Conservation, 21: 113-119.

Saj T.L., Mather C. \& Sicotte P. (2006). Traditional taboos in biological conservation: The case of Colobus vellerosus at the Boabeng-Fiema Monkey Sanctuary, Central Ghana. Social Science Information, 45: 285-310.

Sarfo-Mensah P. \& Oduro W. (2007). Traditional Natural Resources Management Practices and Biodiversity Conservation in Ghana: A Review of Local Concepts and Issues on Change andsustainability, Retrieved from: http://www.feem.it/Feem/Pub/Publications/WPapers/default.htm

Sasaki K., Sasaki Y. \&. Fox S.F. (2010). Endangered traditional beliefs in japan: Influences on snake conservation. Herpetological Conservation and Biology, 5(3): 474-485.

Schachenmann P. (2006). Spiritual values in Madagascar: The starting point for endogenous conservation initiatives. Mountain Research and Development, 26: 323-327.

Tengo M., Johansson K., Rakotondrasoa F., Lundberg J. \& Andriamaherilala J.A. (2007). Taboos and forest governance: Informal protection of hot spot dry forest in Southern Madagascar. Ambio, 36(8): 683-691

Toledo V.M. (2000). Indigenous knowledge on soils: An ethnoecological conceptualization. In: Barrera-bassols \& Zinck J.A. (Eds.) Ethnopedology in a worldwide perspective: An Annotated Bibliography. ITC Publication, pp. 77.

Uloko J.I. \& Yager G.O. (2017). Indigenous Land Tenure System as a Hindrance to the Development of Pandam Wildlife Park, Asian Journal of Environment \& Ecology, 5(2): 1-9.

Wilson E.O. (1989). Conservation: the next hundred years. In: Western D. \& Pearl M. (Eds.) Conservation for the twenty-FirstCentury. Oxford University press, New York/Oxford, pp. 37. 